\title{
Rating groups vs. ratings of group members: evidence from the Italian financial market
}

\author{
Lucia Gibilaro \\ University of Bergamo \\ Gianluca Mattarocci \\ University of Rome Tor Vergata
}

\begin{abstract}
Group membership can impact significantly on the risk exposure of a firm but the evaluation of aggregate features is more complex than the individual analysis of each member, requiring the support of an information analyst able to define judgment that considers also the inter-group relationships and to access to private information collected directly from the group. Rating agencies do not make independent estimates of group ratings, with respect to the rating of the individual group entities, and, in many cases, they do not disclose this information to the market.

This paper examines the relationship between ratings of groups and individual group entities, with a view to assessing the effects of change to the group structure on the rating. The analysis focuses on the financial sector and is limited to the Italian market, which has been characterized in recent years by a strong trend towards concentration. The results achieved by analysing the rating processes by the main international agencies (Fitch, Moody's and Standard and Poor's) show that both the ratings of the groups and the group structure adjusted ratings of the individual entities are not at all affected by the occurrence of significant corporate events regarding the group's structure.
\end{abstract}

Keywords: rating, risk, financial group, organizational structure, corporate events 


\section{Introduction}

Rating agencies offer services that allow to reduce the information asymmetry in the financial markets (Diamond, 1989). These are useful even in more developed financial markets (Partnoy, 1999) in order to reach the correct allocation of financial resources available (Kao and $\mathrm{Wu}, 1990)$. Some authors provide empirical and/or theoretical contributions about the impact of judgment changes on the market (Cowan, 1991) and demonstrate the role of issuers and/or issues characteristics in the rating definition (Cantor, 2004).

The paper analyses the characteristics of the group rating for financial entities and their relevance in the criteria adopted by rating agencies for the judgment on an evaluated entity. The research field regarding groups of firms presents an huge number of theoretical contributions about the more relevant characteristics of the group that could impact on its risk or on members' risk exposure (for the Italian market see, among others, Cassandro, 1969, Azzini, 1968, Pisoni, 1983 and Soda, 1998) but, despite this evidence, there are very few studies in literature on the relationship between group characteristics and rating agency judgment about the group as a whole or the individual issuers / issues (Gaver and Pottier, 2005).

This work analyses this relationship looking at up-rating and down-rating made on the group as a whole and on each group member and studying the impact of corporate events on group rating, focusing for the first time on Italian financial market: since the beginning of the New Millennium, on average the Italian Banking System has experienced the more intense concentration growth in Europe (European Central Bank, 2008), reaching the second level for concentration among the 5 European countries with more relevant banking systems (Bank of Italy, 2008). This study allows to evaluate the degree of coherence of rating agencies services' characteristics and the Basel Committee rules defined for financial intermediaries that adopt the standardized approach (Basel Committee on Banking Supervision, 2006) and it is relevant to evaluate the need of changes in rating agencies' services in order to satisfy the specific request of these new customers.

The paper identifies, on the basis of the literature review (section 2.1) and on the basis of the criteria produced by rating agencies (section 2.2), the main drivers of risk for a financial group and analyses the Italian banking groups in order to investigate the relationship between group rating and rating of group member (section 3.2) and the impact of main corporate events on the judgment of the risk of the group expressed by the rating agency (section 3.3).

The analysis of the rating agencies' criteria highlight that in the period 2000-2007 only Fitch produces an independent judgment of the group characteristics, while other two agencies take the group into account only for the purpose of correcting their evaluation about issuers' and/or issues' risk. The study of the relationship between rating by the agencies and the group characteristics has also shown that the group rating could be considered correlated only with the rating of holding companies and normally the judgment expressed by the rating agency is hardly ever affected by the occurrence of corporate events capable of altering the group's organization and operation.

\section{Literature review}

\subsection{The characteristics of financial groups and their impact on risk}

A financial group is a type of organization wherein ownership is separated from control over a set of legally independent entities (Mottura, 2007); the proprietary relations 
allow a unitary management or, at least, coordination (Brioschi et al., 1990). In a scenario characterised, as in recent years, by an increased concentration of supply, which has reduced the number of independent operators in the various countries (Lown et al., 2000), creating a financial group has represented the most widespread solution for maximising a business' market share (Carretta, 1986).

The structure of a group enables it to operate in different sectors by flexibly exploiting the possible synergies existing among its members (Vander Vennet, 2002), compared to the activities that could be exercised through a single firm; this advantage for a financial group, however, is countered by a potential risk, which can be defined as the increased uncertainty descending from the economic and financial interdependence of the member undertakings, with respect to the unitary management by the holding company (Monferrà and Rigodanza, 2006), which interdependence can absorb the economic and financial resources from the single undertaking to the group and vice versa, thus affecting its risk of insolvency.

The degree of capitalization of the individual member undertakings is affected by the adoption of a consolidated risk management process (Joint Forum, 2008), based on the coordination of the measurement and management of the corporate risks, in order to define the amount of capital to be allocated to the single entities. The implementation of this process is instrumental to the objectives of both the regulators, for the stability and soundness of the financial system as a whole, and the business undertaking, namely, the allocation of capital to activities that allow the achievement of a higher performance adjusted by the risk. Therefore, the fungibility of the capital proposed for allocation within the group enhances the interdependence between the group entities, because the financial resources made available to a group member could be affected by the risks undertaken by another member (Cumming and Hirtle, 2001). Among the criticalities of the implementation of a consolidated risk management process there is the development of consistent methodologies, with respect to different types of risks, products and markets: in the case of heterogeneous groups, the analysis of the main international players has shown that coordination is achieved mainly by pursuing the objective of replicating the behaviour of the more virtuous group members (Edwards, 1999). The degree of liquidity of the group member is a function of the correlation between the cash flows of the group entities (D'Souza and Lai, 2007) and it can be considered as fungible, lacking regulatory constraints, just like the capital. Therefore, the management is predominantly centralised in the hands of the holding company (Basel Committee on Banking Supervision, 2000), through a system of internal transfer rates (Masini, 1988). The structure of the group affects the profit-producing capacity of the single members by means of the distribution of fixed costs over a larger number of products and services in order to achieve economies of scale (Berger and Hannan, 1998) and economies of scope (Teece, 1980). However, this objective can be achieved only providing that (i) expansion within the same sector does not lead to expansion towards more risky activities (Demsetz and Strahan, 1997) and (ii) the higher degree of diversification - which is a typical feature that Italian financial groups achieved through dimensional growth (Guatri and Bini, 2007) - does not lead to the worsening of its systemic risk (Allen and Jagtiani, 2000).

The group structure changes as a result of the transactions that can alter the number of controlled entities, with implications on the group's legal organization, such as the merger and takeover operations (Baravelli, 2003), or events that can change the internal organization through changes to its geographical organization, such as the disposal of local branches and/or single assets and liabilities (Ruozi, 2006).

\subsection{The criteria employed by the rating agencies and the significance of the group}


The structure of a banking group is analyzed through the ratings criteria produced by the main agencies operating on the international financial market, i.e. Fitch Ratings, Moody's Investors Service and Standard and Poor's. The procedures for taking into account several distinctive features of the group comprise a second-tier issuer rating, by assigning a support rating to the issuer, or adapting the individual rating criteria, with respect to both the issuer and the issue (Table 1).

Table 1. The significance of groups in agency ratings on the basis of the published criteria

\begin{tabular}{|l|l|l|l|l|}
\hline \multicolumn{2}{|c|}{} & Rating agency & \multicolumn{3}{|l|}{} \\
\cline { 3 - 5 } \multicolumn{2}{|c|}{} & Fitch Ratings & $\begin{array}{l}\text { Moody's Investors } \\
\text { Service }\end{array}$ & $\begin{array}{l}\text { Standard and } \\
\text { Poor's }\end{array}$ \\
\hline $\begin{array}{l}\text { Group } \\
\text { ratings }\end{array}$ & Type of rating & Support rating & Not available & Not available \\
\cline { 2 - 5 } & Source & $\begin{array}{l}\text { Bank rating } \\
\text { methodology }\end{array}$ & Not available & Not available \\
\hline $\begin{array}{l}\text { Corrected } \\
\text { group } \\
\text { rating }\end{array}$ & Type of rating & Issuer rating & $\begin{array}{l}\text { Corrected issue } \\
\text { ratings for the group }\end{array}$ & $\begin{array}{l}\text { Corrected issuer } \\
\text { ratings for the group }\end{array}$ \\
\cline { 2 - 5 } & Source & $\begin{array}{l}\text { Bank rating } \\
\text { methodology }\end{array}$ & $\begin{array}{l}\text { Bank Short- term } \\
\text { and Long- Term } \\
\text { Bank Deposit Rating }\end{array}$ & $\begin{array}{l}\text { Banks } \text { Friteria: Group } \\
\text { Methodology for } \\
\text { Financial Services } \\
\text { Companies }\end{array}$ \\
\hline
\end{tabular}

Source: data processed by authors based on the agencies' criteria

Fitch Ratings (hereinafter Fitch) rates banks according to both an Individual Rating and a Support Rating, based on the agency's assessment of the capacity, timeliness and effectiveness of the support to the entity to which the Individual Rating refers, by the ownership or the State (Fitch, 2004). Considering a comparable value of State support, the Support Rating can change according to the characteristics of the ownership, excluding from the assessment the intervention, if any, of families or individuals participating in the entity's capital. In particular, the agency assesses: the legal guarantees, if any, undertaken by the ownership; the controlling stake; the nature of the ownership; the entity's importance for the ownership. As a whole, these aspects define the banking group's institutional structure (Baravelli, 2003): external intervention in the event of a crisis depends on the financial support of the holding company, which is ultimately influenced by the capital allocated to the other group members. The significance of the group assessment determines the coincidence of the minimum long-term rating of the issues of the individual undertakings with the Support Rating. Moving on to the adaptations of the criteria, to take account of the group structure, the agency assesses the group structure to determine the Individual Rating of the holding company, which does not carry out operating activities within the group. In this case, the rating is aligned with that of the main financial firms within the group, highlighting any disalignments, limited to one rating notch, in respect of the degree of liquidity, the approach to risk management and submission to supervision (Fitch Ratings, 2006). Having regard to the determination of the Individual Rating of the individual group companies, the influence of the group structure may be analysed; in fact, although the aim is to assess the issuer's risk, based on the assumption of the full independence of the undertaking and regardless of any external support, the criteria support the relevance of corporate governance on performance (Ertugrul and Shantaram, 2010) by providing a focused information area where, the agency takes account of the group membership by considering the legal structure of the consolidation; its relations with the holding company and the other group entities; the centralisation/delocalisation of the control activities over the group undertakings. 
Moody's Investors Service (hereinafter Moody's) does not assign an issuer rating in consideration of the assessed entity's dependence on another controlling undertaking (Moody's, 1999) during the timeframe of the study. The methodology adopted for bank issuer ratings - the Bank Financial Strength Rating - rates the banks based on an assumption of full independence (Moody's, 2006). The agency takes external support into account in respect of the criteria for the banks' debt ratings, i.e. the Bank deposit ratings (Moody's, 2003), although the transparency of the assessment procedures appears to be limited.

Standard and Poor's rating agency (hereinafter S\&P) does not provide for an additional public issuer rating, with respect to an entity belonging to a group, but, rather, the adjustment of the single criteria; for $\mathrm{S} \& \mathrm{P}$, in fact, the issuer rating of a bank is a function, inter alia, of the corporate structure (Standard and Poor's, 2004a). In connection with the assessment of the corporate structure, the agency takes into account the bank's membership of a financial group when formulating its judgment: it adapts the rating of the individual entity in the light of the group's legal capacity and effectiveness, in respect of providing support to the bank during a crisis (Standard and Poor's, 2004b). To appreciate this support, the agency implements an assessment process aimed to establish the overall group risk and, based on the composition of the group and of the position of the assessed member, with respect to the group's structure and long-term strategy, its attitude to provide financial support. The agency believes that, even in the assumption of the isolation of the riskier activities/entities, the group assessment should take them into account. Therefore, for the purpose of issuer rating the group undertakings, the agency implements a process consisting of the following phases: a) the financial analysis of the group; b) the individual and confidential rating of the group entities; c) the public rating of the assessed entity, in relation to its role within the group structure. In phase one, the agency determines the group's core group ratings, as an aggregation of the holding and of the individual significant undertakings, with respect to their size and risk (core undertakings): these core group ratings are the starting point for the subsequent rating of the individual group members. Like Fitch, the rating of the non-operational holdings is achieved on the basis of the reduction of the core group ratings by between 1 and 3 notches. In phase two, the agency determines, first of all, the individual ratings of the entities, assuming their independence within the group, and then adapts the individual rating in relation to the expected support characteristics of the group, with respect to the entity undergoing a crisis, by means of the status quo rating. In phase three, S\&P carries out the public rating based on the entity's status within the group. In the case of core undertakings, $\mathrm{S} \& \mathrm{P}$ assigns the core group ratings; group entities judged by $\mathrm{S} \& \mathrm{P}$ to be strategic are assessed according to a rating that is one degree higher than the status quo rating; in the case of non-strategic undertakings, $\mathrm{S} \& \mathrm{P}$ assigns a public rating equal to the status quo rating. The agency admits the possibility of a higher public rating of the individual group entities compared to the core group ratings, when the activities carried out, the endowment and the financial separation with respect to the group can justify a higher-class segmented rating compared to the group rating.

The comparative analysis of the procedures by means of which the agencies consider an entity's membership of a group highlights that, as a rule, the assessment of the group alters the issuer's - or the issue's - rating, although the methodologies differ greatly by degree of transparency, which is higher for S\&P compared to Fitch and, even more, Moody's. Generally speaking, the relationship between the assessment of the individual entities and the overall group is significantly affected by the individual entity's role within the group: as the assessment of the group is an appreciation by the single agency, which is not necessarily shared with the holding company, it is believed that this aspect may negatively affect the agency's capacity to assess the group's long-term strategy. 


\section{Empirical analysis}

\subsection{The sample}

The data relating to the composition of the Italian banking groups and the financial statements for each group member are collected through ABI banking data (hereinafter ABI) and cover the period from 2000 to $2007^{1}$. The sample is representative of the entire Italian market and includes 83 banking groups, which differ by number of members and type of entities included in the group, totalling 1215 entities examined (Graph 1).

\section{Graph 1. The characteristics of Italian banking groups}

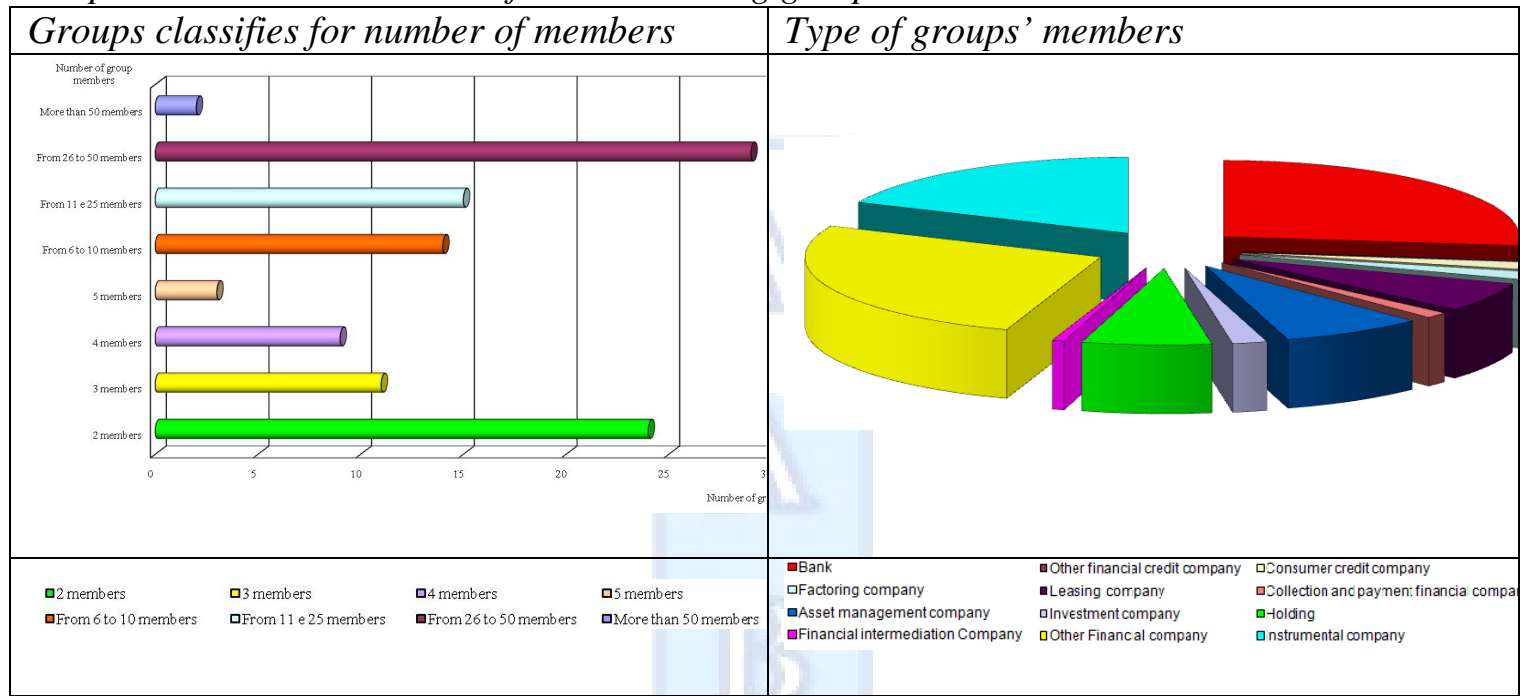

Source: ABI data processed by the authors

The rating analysis relating to the groups and group members has been carried out based on the judgments by the main worldwide rating agencies: Fitch, Moody's and S\&P 2 . The focus is on the ratings assigned by the three agencies to the groups as a whole and to each group member (issuer and issue rating), collecting the information from the Bloomberg Finance L.P. database (hereinafter Bloomberg).

A first analysis of the sample of available data highlights significant differences within each groups in terms of rated entities (Graph 2).

\section{Graph 2. Sample characteristics}

The ratings of the holding company and of the group's members

Number of entities in the group with at least one rating available during all the time horizon

\footnotetext{
${ }^{1}$ In Italy, based on the Consolidated Banking Act (article 60 et seq.), the only legally allowed financial groups are those with a holding company represented by an Italian-based bank or a financial company based in Italy.

${ }^{2}$ The decision to exclude the other agencies (AM Best, Dun \& Bradstreet, Japan Credit Rating Agency Rating \& Investment Information) does not impair the general significance of the empirical analysis because these agencies, in the period considered, mainly rated Treasury bond issues and issues made by non-financial firms and only twenty ratings belong to financial groups members.
} 


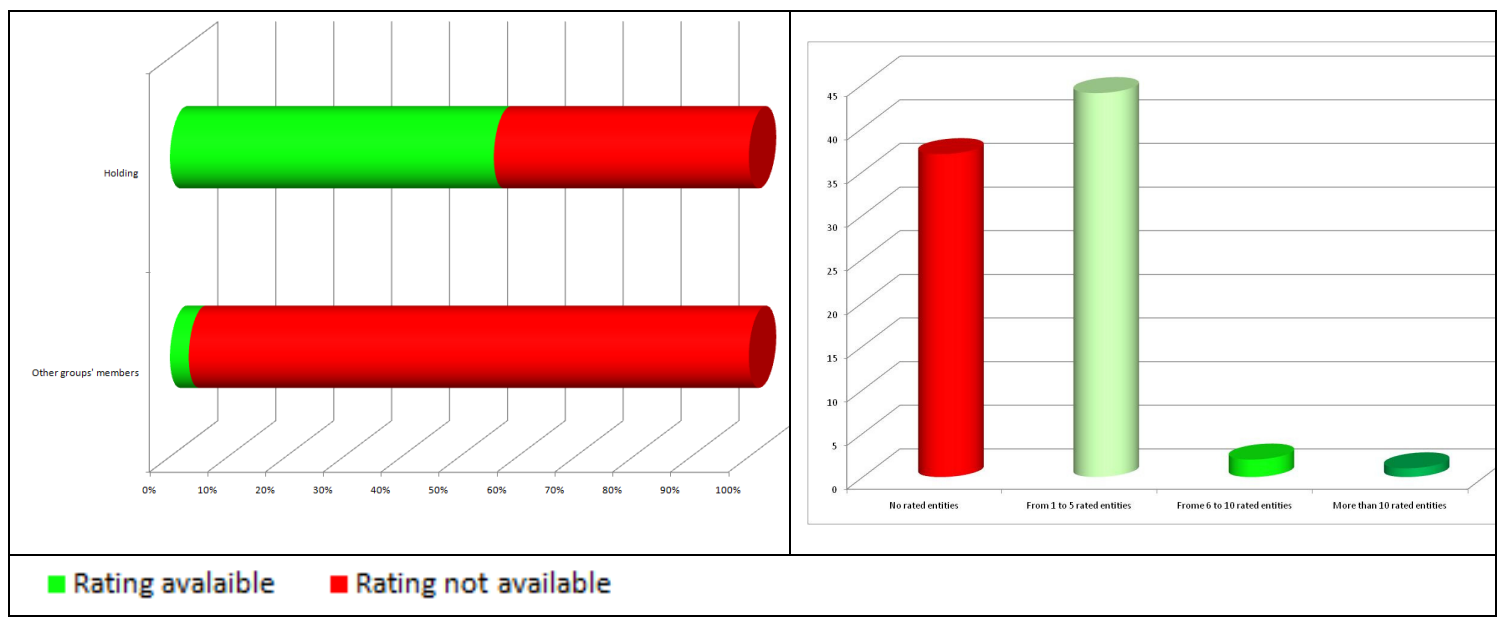

Source: Bloomberg data processed by the authors

The international rating agencies ensure a good coverage of the holding companies of the Italian banking groups (approximately 56\% of the holding companies are rated), while only a very small number of group entities are rated (just over $3 \%$ of the members). Therefore, by analysing the single groups for which rating judgments are available, it is possible to identify mostly groups with no more than 5 rated entities (over $93 \%$ of the groups).

\subsection{The relationship between group and individual group-member ratings}

The first analysis concerned group ratings and the rating of the individual group members, with a view to identifying the possibility of establishing a relationship between the judgment of certain types of members and the overall judgment of the group by an agency. For this purpose, the ratings issued by the agencies were analysed to identify only the judgments that - based on the analysis of the criteria used by the agencies - may be associated solely with the group characteristics and those related only to the characteristics of the single issuer (Graph 3).

Graph 3. The types of rating available for the Italian banking sector

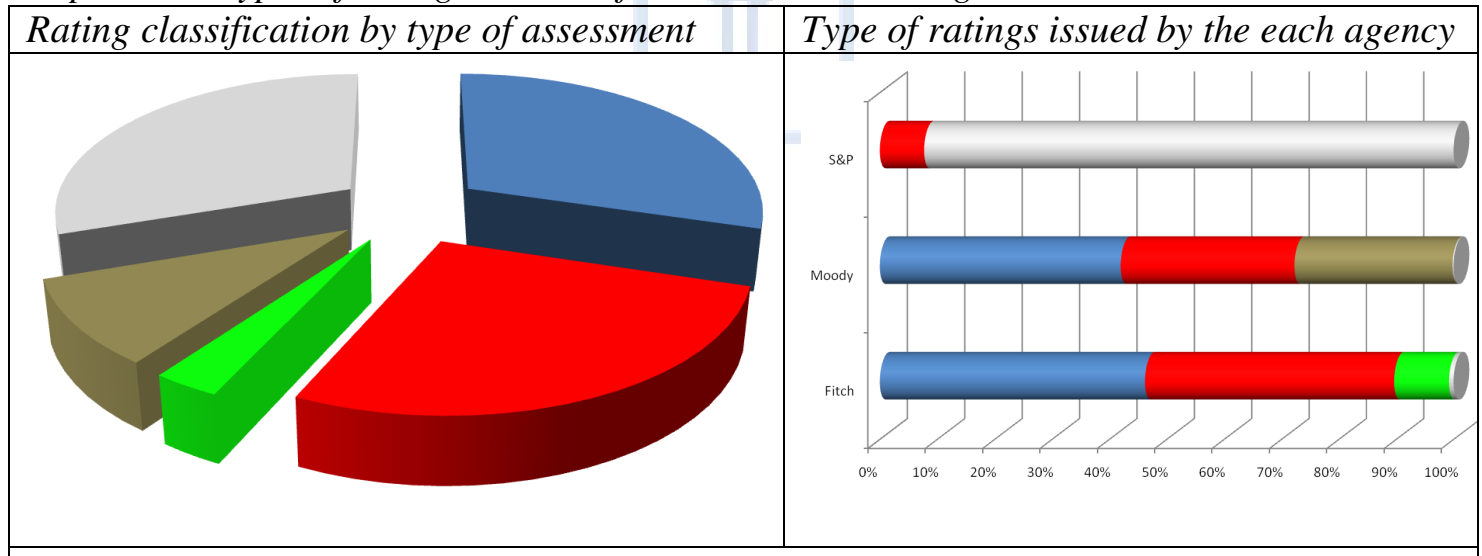

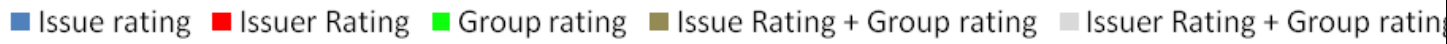


A survey of the Italian market has highlighted a considerable amount of ratings related only to the characteristics of the single issues by the group or one of its member undertakings (38.23\% of the cases) and a limited amount of judgments based only on the bank group characteristics $(3.08 \%)$. The separate disclosure of the issuer and the group assessment, however, is practised only by Fitch, with respect to which, in the period considered, 582 changes were surveyed regarding the issuer rating and 58 changes regarding the group ratings. Other agencies consider the characterising aspects of the group directly with respect to the definition of the issue ratings (Moody's) or issuer ratings ( $\mathrm{S} \& \mathrm{P}$ ) and do not produce any independent estimates of the group's risk profile.

The analysis of several descriptive statistics of the rating performance of the group issued by Fitch highlights several recurring characteristics of the judgment of the group's qualities (Table 2).

Table 2. The characteristics of banking groups rating released by Fitch

\begin{tabular}{|c|c|c|c|c|c|}
\hline \multicolumn{2}{|l|}{ Name of banking group } & & $\begin{array}{l}\text { Average } \\
\text { rating* }\end{array}$ & $\begin{array}{l}\text { Number of } \\
\text { rating changes }\end{array}$ & $\begin{array}{l}\text { Number of } \\
\text { notch } \\
\text { changes }\end{array}$ \\
\hline \multicolumn{2}{|l|}{ ANTONVENETA } & 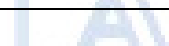 & 2,67 & 1 & 2 \\
\hline \multicolumn{2}{|c|}{ BANCA DI CREDITO POPOLARE SCRL } & +2 & 3,42 & 3 & 0 \\
\hline \multicolumn{2}{|c|}{ BANCA IFIS } & & 2,00 & 0 & 0 \\
\hline \multicolumn{2}{|l|}{ BANCA ITALEASE } & & 3,50 & 1 & 0 \\
\hline \multicolumn{3}{|c|}{ BANCA POPOLARE DELL'ETRURIA E DEL LAZIO } & 4,00 & 0 & 0 \\
\hline \multicolumn{2}{|c|}{ BANCA POPOLARE DI SONDRIO } & & 2,00 & 1 & 0 \\
\hline \multicolumn{2}{|c|}{ BANCA POPOLARE DI VICENZA } & +2 & 4,00 & 1 & 0 \\
\hline \multicolumn{2}{|l|}{ BANCO DESIO } & & 4,00 & 1 & 0 \\
\hline \multicolumn{2}{|l|}{ BNL } & & 5,00 & 1 & 0 \\
\hline \multicolumn{2}{|l|}{ BPER } & & 4,00 & 1 & 0 \\
\hline \multicolumn{2}{|l|}{ BPIEMME } & & 2,00 & 1 & 0 \\
\hline \multicolumn{2}{|l|}{ CAPITALIA } & +2 & 2,89 & 3 & 2 \\
\hline \multicolumn{2}{|l|}{ CARIGE } & & 2,00 & 1 & 0 \\
\hline \multicolumn{2}{|c|}{ CREDITO VALTELLINESE } & & 2,00 & 0 & 0 \\
\hline \multicolumn{2}{|l|}{ ICCREA } & & 2,50 & 3 & 0 \\
\hline \multicolumn{2}{|l|}{ INTESA SAN PAOLO } & & 3,50 & 0 & 0 \\
\hline \multicolumn{2}{|l|}{ INTESA SAN PAOLO } & +2 & 3,50 & 0 & 0 \\
\hline \multicolumn{2}{|l|}{ MPS } & & 3,50 & 2 & 0 \\
\hline \multicolumn{2}{|l|}{ VENETO BANCA } & & 3,50 & 1 & 2 \\
\hline \multicolumn{2}{|l|}{ ANTONVENETA } & +1 & 2,67 & 1 & 2 \\
\hline \multicolumn{6}{|c|}{$\begin{array}{l}\text { FINANCIAL GROUPS RATING DYNAMICS IN OTHER COUNTRIES** (EURO AREA at } 2007+\text { UK } \\
\text { and US ) }\end{array}$} \\
\hline \multirow{2}{*}{ and US ) } & \multirow{2}{*}{$\begin{array}{l}\mathrm{N}^{\circ} \text { rated } \\
\text { entities }\end{array}$} & \multicolumn{2}{|c|}{ Overall country } & \multicolumn{2}{|c|}{$\begin{array}{l}\text { Group with highest rating } \\
\text { variability of rating } \\
\text { assigned }\end{array}$} \\
\hline & & $\begin{array}{l}\text { Number of } \\
\text { rating } \\
\text { changes }\end{array}$ & $\begin{array}{l}\text { Number of } \\
\text { notch changes }\end{array}$ & $\begin{array}{l}\text { Number of } \\
\text { rating } \\
\text { changes }\end{array}$ & $\begin{array}{l}\text { Number of } \\
\text { notch } \\
\text { changes }\end{array}$ \\
\hline AUSTRIA & 7 & 5 & 0 & 6 & 0 \\
\hline BELGIUM & 6 & 4 & 0 & 3 & 0 \\
\hline CYPRUS & 0 & 0 & 0 & 0 & 0 \\
\hline FINLAND & 4 & 2 & 0 & 1 & 0 \\
\hline FRANCE & 33 & 30 & 0 & 4 & 0 \\
\hline GERMANY & 37 & 41 & 2 & 7 & 2 \\
\hline GREECE & 6 & 2 & 2 & 2 & 2 \\
\hline IRELAND & 0 & 0 & 0 & 0 & 0 \\
\hline LUXEMBOURG & 11 & 4 & 0 & 3 & 0 \\
\hline MALTA & 6 & 8 & 0 & 2 & 0 \\
\hline
\end{tabular}




\begin{tabular}{|c|c|c|c|c|c|}
\hline PORTUGAL & 0 & 0 & 0 & 0 & 0 \\
\hline SLOVAKIA & 6 & 8 & 0 & 3 & 0 \\
\hline SLOVENIA & 7 & 9 & 0 & 3 & 0 \\
\hline SPAIN & 47 & 51 & 0 & 5 & 0 \\
\hline THE NETHERLANDS & 10 & 8 & 1 & 7 & 1 \\
\hline UNITED KINGDOM & 40 & 39 & 2 & 4 & 2 \\
\hline UNITED STATES & 329 & 97 & 19 & 6 & 2 \\
\hline
\end{tabular}

Source: Bloomberg data processed by the authors

By assuming that the variability of sovereign ratings is scarce for developed countries (Bissoondoyal-Bheenick, 2005), the judgment of the examined banking groups can be considered hardly variable over the years, because, in the seven-year period taken into account, the agency did not make a change higher respect to one rating class for the majority of examined groups (about 79\%) and, with regard to the extent of the changes made, this was below the average of European countries more audited by Fitch (France, Germany and Spain) and not comparable with the dynamics of support rating for UK and US groups; on the contrary, as regards the notches assigned, this was more significant compared to European country dynamics and only the US groups are more affected by notches changed. The poor comparability of the results with the US reflects the difference of the consolidation pattern of banking groups respect to Europe (Cybo-Ottone, Murgia 2000) even though, in the last decade, the process was more sustained in Europe than in the rest of the world (Goddard et al., 2007). The behaviour adopted by the agency, therefore, in the case of banking groups, features a lower propensity to make significant changes to the ratings and a preference for the use of notches to express any changes recorded in the period.

This result appears even more significant if we consider the events concerning the various groups in the period analysed, and which - based on the previously proposed review of the literature on the subject - should have influenced the agency's judgment (Graph 4).

Graph 4. The events concerning the banking groups assessed by Fitch and broken down by

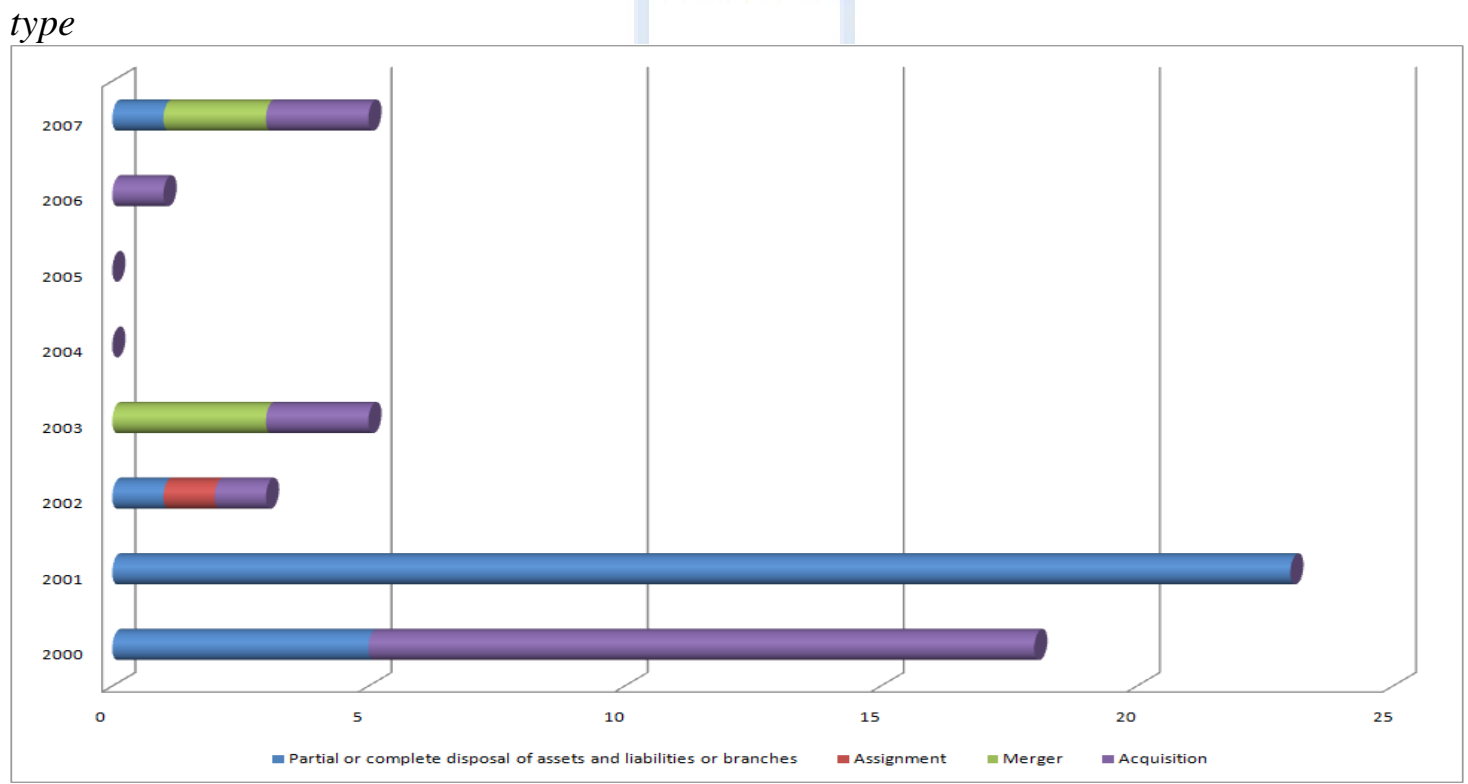

Source:ABI and Bloomberg data processed by the authors

Rating groups vs. ratings, Page 9 
In the 2000-2007 period, frequent disposals of assets/liabilities and of branch offices were reported, especially during the first two years, and a noteworthy number of extraordinary financial transactions (mergers and acquisitions) were carried out, which have significantly modified the number of entities belonging to the single groups.

Moreover, the comparison between the ratings issued with respect to the group and the single group members highlights that this anomaly did not concern all the assessments made by the agency, as the ratings regarding the individual issuers were much more variable in time (Table 3).

Table 3. The characteristics of Fitch ratings assessed for individual group members

\begin{tabular}{|c|c|c|c|c|c|c|c|c|c|c|c|c|c|c|}
\hline \multirow{2}{*}{\multicolumn{4}{|c|}{ Name of bank group }} & \multicolumn{4}{|c|}{$\begin{array}{l}\text { Number of notch } \\
\text { changes in the } \\
\text { period }^{*}\end{array}$} & \multicolumn{4}{|c|}{$\begin{array}{l}\text { Number of rating } \\
\text { changes in the period* }\end{array}$} & \multicolumn{3}{|c|}{$\begin{array}{l}\text { Correlation } \\
\text { between rating of } \\
\text { members and group } \\
\text { rating** }\end{array}$} \\
\hline & & & & \multicolumn{2}{|c|}{$\begin{array}{l}\text { Holding } \\
\text { compan } \\
\mathrm{y}\end{array}$} & \multicolumn{2}{|c|}{\begin{tabular}{|l|} 
Other \\
member \\
$\mathrm{s}$
\end{tabular}} & \multicolumn{2}{|c|}{$\begin{array}{l}\text { Holding } \\
\text { company }\end{array}$} & \multicolumn{2}{|c|}{\begin{tabular}{|l|} 
Other \\
member \\
$\mathrm{s}$
\end{tabular}} & $\begin{array}{l}\text { Holding } \\
\text { compan } \\
\mathrm{y}\end{array}$ & \multicolumn{2}{|c|}{$\begin{array}{l}\text { Other } \\
\text { member } \\
\mathrm{s}\end{array}$} \\
\hline \multicolumn{4}{|c|}{ ANTONVENETA } & 3 & & \multicolumn{2}{|l|}{-} & \multicolumn{2}{|l|}{1} & \multicolumn{2}{|c|}{-} & $89.00 \%$ & \multicolumn{2}{|l|}{-} \\
\hline \multicolumn{4}{|c|}{$\begin{array}{l}\text { BANCA DI CREDITO POPOLARE } \\
\text { SCRL }\end{array}$} & 2 & 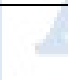 & \multicolumn{2}{|c|}{-} & \multicolumn{2}{|l|}{1} & \multicolumn{2}{|l|}{ - } & $0.00 \%$ & \multicolumn{2}{|l|}{-} \\
\hline \multicolumn{4}{|c|}{ BANCA IFIS } & 2 & & \multicolumn{2}{|l|}{-} & \multicolumn{2}{|l|}{0} & \multicolumn{2}{|c|}{-} & $0.00 \%$ & - & \\
\hline BANCA & ALEASH & & & 1 & & - & & 1 & & - & & $0.00 \%$ & - & \\
\hline $\begin{array}{l}\text { BANCA } \\
\text { E DEL L }\end{array}$ & $\begin{array}{l}\text { POLAR } \\
\text { IO }\end{array}$ & ELL'ET & RIA & 3 & & - & & 0 & & - & & $81.00 \%$ & - & \\
\hline BANCA & POLAR & I SOND & & 1 & & - & & 0 & & - & & $-52.00 \%$ & - & \\
\hline BANCA & POLAR & I VICEN & & 1 & & - & & 0 & & - & & $27.00 \%$ & - & \\
\hline BANCO & $\mathrm{SIO}$ & & & 1 & 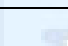 & - & & 1 & & - & & $0.00 \%$ & - & \\
\hline $\mathrm{BNL}$ & & & & 8 & & - & & 6 & & - & & $97.00 \%$ & - & \\
\hline BPER & & & & 5 & & 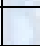 & & 2 & & - & & $0.00 \%$ & - & \\
\hline BPIEMN & & & & 1 & - & - & & 1 & & - & & $14.00 \%$ & - & \\
\hline CAPITA & & & & 2 & & - & & 0 & & - & & $-18.00 \%$ & - & \\
\hline $\mathrm{CARICH}$ & & & & 8 & & 1 & & 3 & & 0 & & $0.00 \%$ & & $0 \%$ \\
\hline CARIGE & & & & 2 & & 0 & & 1 & & 0 & & $0.00 \%$ & & $0 \%$ \\
\hline CREDIT & MILIA & & & 1 & & - & & 0 & & - & & $53.00 \%$ & - & \\
\hline CREDIT & IALTEI & NESE & & 1 & 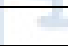 & - & & 0 & & - & & $52.00 \%$ & - & \\
\hline DEXIA & & & & 1 & & 1 & & 1 & & 0 & & $0.00 \%$ & & $0 \%$ \\
\hline ICCREA & & & & 0 & & - & & 0 & & - & & $0.00 \%$ & - & \\
\hline INTESA & $\mathrm{NPAO}$ & & & 2 & & - & & 1 & & - & & $27.00 \%$ & - & \\
\hline MPS & & & & 4 & & 3 & & 2 & & 0 & & $32.00 \%$ & & $00 \%$ \\
\hline UBI BA & & & & 1 & & - & & 0 & & - & & $90.00 \%$ & - & \\
\hline UNIPOL & & & & 2 & r & & & 1 & & - & & $43.00 \%$ & - & \\
\hline VENETC & ANCA & & & 2 & & - & & 1 & & - & & $0.00 \%$ & & \\
\hline $\begin{array}{l}\text { Notes: } \\
-=\text { Nor } \\
{ }^{*}=\text { In th } \\
{ }^{* *} \text { For co } \\
\text { following }\end{array}$ & $\begin{array}{l}\text { dentitie. } \\
\text { alysis of } \\
\text { lation es } \\
\text { iteria: }\end{array}$ & $\begin{array}{l}\text { ailable in } \\
\text { ing varic } \\
\text { ates the } i\end{array}$ & idua & con & $\begin{array}{l}\text { dered } \\
\text { assi }\end{array}$ & the & tra & & $\begin{array}{l}\text { ing as } \\
\text { d into }\end{array}$ & & $\begin{array}{l}\text { to eac } \\
\text { rical va }\end{array}$ & $\begin{array}{l}\text { hissuer } \\
\text { lues using }\end{array}$ & & \\
\hline Rating & Value & Rating & Valu & & Rati & & $\mathrm{Va}$ & & Rati & & Value & Rati & & Valu \\
\hline AAA & 1 & $\mathrm{~A}$ & 4 & & BB & & 6 & & $\mathrm{CCC}$ & & 7 & $\mathrm{C}$ & & 9 \\
\hline AA & 2 & BBB & 5 & & B & & 7 & & $\mathrm{CC}$ & & 8 & D & & 10 \\
\hline
\end{tabular}

Source: Bloomberg data processed by the authors

The variability of the group members' ratings is significantly higher compared to that of the overall groups, while the use of notches to express changes to the judgment of the 
single members was used primarily to alter the holding company rating, rather than that of the individual member. The comparison of these results with the rating dynamics of Italian nonbanking groups highlights a higher degree of reactivity of the holding company ratings of financial groups compared to the other holding companies, and a lesser focus, by the rating agency, to change the notches or ratings of the other members of the industrial group.

The judgment relating to the holding company seems to positively affect the judgment relating to the group (except in two cases), although it cannot be claimed that the two judgments always mutually affect each other, since there are many cases (over 33\%) in which the surveyed degree of correlation amounts to nil. The analysis of the correlation between the group rating and the rating of the individual members highlights that, if available, the rating of the other group members is hardly significant (in one case only the value of the correlation index exceeds 0 ).

The comparison of these dynamics with the behaviour of the agency with respect to resident non-banking groups highlights a higher correlation between the non-banking group ratings and the ratings of the holding company (about 82\%) and the group members (about 55\%). This result establishes that, in the case of the industrial undertakings assessed by Fitch there is a strong unitary strategic vision that, unlike in the case of banking groups, determines a higher consistency with the rating of the individual group members.

\subsection{The impact on the rating of changes to the group characteristics}

The limited rating frequency of the individual group undertakings and the limited number of cases in which the rating of several group undertakings deviates significantly from the group rating, prevents us from endorsing the fact that the group rating is independent of the characteristics of the individual members.

An alternative approach to the assessment of the role played by the group structure in the agencies' assessment process may take account of the impact of any sensitive events, identified on the basis of the criteria published by the agencies, on the rating. The analysis has been carried out using an approach based on the traditional event study applied directly to the recorded change in the rating, with a view to assessing the significance of the events affecting the banking group for rating purposes. An estimate of the abnormal trend based on the formula is measured as follows:

$$
\Delta R T G_{i t}=\mid \text { Rating }_{i t}-\text { Rating }_{i t-1} \mid
$$

where the Rating Variation $\left(\triangle R T G_{i}\right)$ is the absolute value of the difference - for each day between the rating in the period $\left(\right.$ Rating $\left._{i}\right)$. In order to estimate the difference between the rating assigned in one day respect to the previous one, all rating are transformed into numerical values on the basis of criteria presented in table 5 .

Table 5. Conversion criteria for rating classes into numerical values

\begin{tabular}{|c|c|}
\hline Criterion & Value assigned \\
\hline Difference of $n$ rating classes & $\mathrm{n}$ \\
\hline Difference of $n$ notches ${ }^{*}$ & $\mathrm{n} / 6$ \\
\hline
\end{tabular}


The significance of each single event on the agency's rating has been determined considering the abnormal rating trends in the proximity of the date on which the significant event occurred, according to the formula:

$$
C \Delta R T G_{i}{ }^{n}=\sum_{t=1}^{n} \Delta R T G_{i t}=\sum_{t=1}^{n} \mid \text { Rating }_{i t}-\text { Rating }_{i t-1} \mid
$$

where the Cumulative Rating Change is determined as the sum of the absolute value of $\triangle R T G i t$ recorded within the event window of $n$ days.

In order to evaluate the timing of the revision, is also created a duration index in order to evaluate also the timeline of revisions decided by the rating agency. In formulas:

$$
\operatorname{DRTG}_{i}{ }^{n}=\sum_{t=1}^{n}(n-t) \times \frac{\mid \text { Rating }_{i t}-\text { Rating }_{i t-1} \mid}{\sum_{i=1}^{n} \mid \text { Rating }_{i t}-\text { Rating }_{i t-1} \mid}
$$

This index assume value from 0 to $\mathrm{n}$ and an increasing value of the index identify a scenario in which rating revision are realised prevalently at the end of the time horizon considered. This measure is expressed in number of days and so value assumed will vary from 0 to the maximum length of the event window.

The domestic supervisory instructions on banking groups identify the relevant events that are able to modify the group structure (Bank of Italy, 1999) : these events are recorded by the ABI database. In the period analysed, , we have considered all the events recorded in the ABI database regarding groups where at least one of the members was assessed by a rating agency ${ }^{3}$ (Table 5).

Table 5. Significant corporate events regarding Italian banking groups in 2000-2007

\begin{tabular}{|l|l|l|l|}
\hline \multirow{2}{*}{ Type of corporate event } & \multirow{2}{*}{ Total Italy } & \multicolumn{3}{|l|}{ Bank group transactions } \\
\cline { 3 - 4 } & & Acquirers rated & Acquired rated \\
\hline Disposal of assets and liabilities - branches & 114 & 64 & 37 \\
\hline Assignments & 2 & 1 & 1 \\
\hline Mergers & 52 & 10 & 5 \\
\hline Acquisition & 156 & 70 & 21 \\
\hline Compulsory liquidation & 1 & 0 & 0 \\
\hline Voluntary liquidation & 10 & 0 & 0 \\
\hline
\end{tabular}

Source: ABI and Bloomberg data processed by the authors

To assess the changes determined by the event, we must first define the time horizon (event window), as a function of the phenomenon analysed and of the frequency of data (MacKinlay, 1997). Based on the criteria produced by the agencies, the judgment regarding issues and issuers had to be re-examined each time a significant event occurs and, therefore, there is no minimum or standard time horizon in which to assess the agency's capability of updating its judgments.

With respect to the analysis, the choice was not to establish a single event window, but to assess the results based on a number of event windows, as a means of viewing the agency's capacity to anticipate the events and to react to their occurrence. In order to identify the

\footnotetext{
${ }^{3}$ Compared to the total transactions recorded, we chose not to consider certain events that concerned the Italian group, but which can hardly be through to impact the group's risk profile, such as, for example, changes to the group's name, to the ABI code number and to the intermediary's legal status.
} 
length of the event window in a non-arbitrary manner, we considered the ratings carried out by the three agencies of the Italian issuers/issues and calculated the average time between two successive assessments (Table 6).

Table 6. Descriptive statistics of rating changes for Italian banking groups' members in 2000-2007

\begin{tabular}{|l|l|l|l|l|l|l|}
\hline \multirow{2}{*}{ Descriptive statistics } & Fitch & \multicolumn{2}{l|}{ Moody's } & \multicolumn{2}{l|}{ S\&P } \\
\cline { 2 - 7 } & Days & Months & Days & Months & Days & Months \\
\hline Mean & 133.97 & 4.47 & 160.74 & 5.36 & 121.81 & 4.06 \\
\hline Minimum & 0.00 & 0.00 & 0.00 & 0.00 & 0.00 & 0.00 \\
\hline Maximum & 2615.00 & 87.17 & 2198.00 & 73.27 & 2687.00 & 89.57 \\
\hline Standard deviation & 300.74 & 10.02 & 384.15 & 12.81 & 361.66 & 12.06 \\
\hline
\end{tabular}

Source: ABI and Bloomberg data processed by the authors

Based on the results of the study of the descriptive statistics relating to the overall sample, it is possible to highlight a significant variability of the time horizon between two issue ratings by the agencies regarding the same issuer. The selected event window length is 5 months (150 days), representing the approximated value of the average rating agencies' mean delay, weighted on the basis of the number of revisions made by each agency in the observed period. In the study, in line with the approaches adopted in the other works on the event study, it was decided to consider three different specifications of the event window considering the 150 days prior the event (ex-ante event window), the 150 days subsequent to the event (ex-post event window), or building a event window of 150 days centred respect to the date thereof (infra event window).

The analysis took account of the $\triangle$ RTG and the DRTG in the proximity of the event and segmented the sample as a function of the rating agency releasing the judgment, the type of judgment (issuer or issue rating), the time horizon of the evaluation (short or medium-tolong term) and the nature of the event ${ }^{4}$. The analysis of the significance of the events, therefore, was carried out taking into account several summary statistics (mode, maximum and minimum), calculated separately for the notches and the rating classes for all the undertakings concerned by the event and assessed by the rating agency ${ }^{5}$ (Table 7).

Table 7. Statistics on CARTG e DARTG near to the groups' corporate events (mean, standard deviation and $t$-test on mean difference)

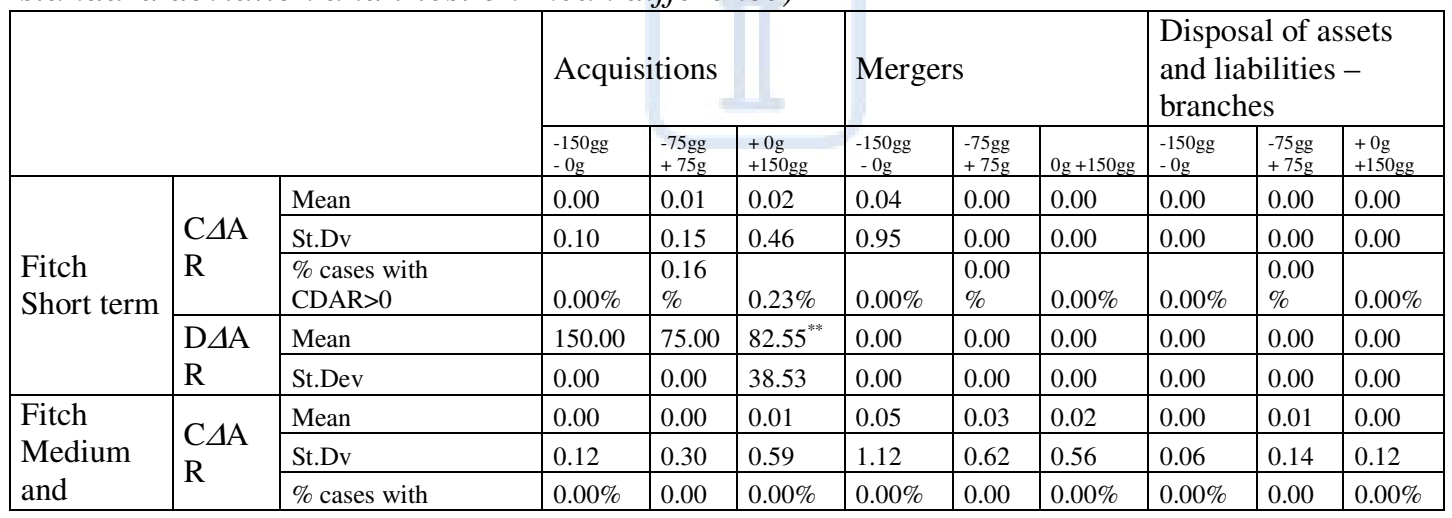

\footnotetext{
${ }^{4}$ For more information on the techniques for interpreting the standard event study approaches, see Bowman (1983).

${ }^{5}$ The analysis of the distribution characteristics of the available ratings does not enable us to approximate the trend recorded with the standard probability functions used for building the test, based on the verification of the assumptions, and therefore the application of these tests for the purpose of verifying the statistical significance of the estimate is useless.
} 


\begin{tabular}{|c|c|c|c|c|c|c|c|c|c|c|c|}
\hline \multirow{3}{*}{$\begin{array}{l}\text { Long } \\
\text { term }\end{array}$} & & CDAR $>0$ & & $\%$ & & & $\%$ & & & $\%$ & \\
\hline & \multirow{2}{*}{$\begin{array}{l}\mathrm{D} \triangle \mathrm{A} \\
\mathrm{R}\end{array}$} & Mean & 150.00 & 75.00 & $76.05^{*}$ & 150.00 & 75.00 & 0.00 & 86.71 & 43.40 & $17.93^{*}$ \\
\hline & & St.Dev & 0.00 & 0.00 & 44.73 & 0.00 & 0.00 & 0.00 & 0.00 & 0.00 & 9.31 \\
\hline \multirow{5}{*}{$\begin{array}{l}\text { Moody's } \\
\text { Short term }\end{array}$} & \multirow{3}{*}{$\begin{array}{l}\mathrm{C} \Delta \Delta \mathrm{A} \\
\mathrm{R}\end{array}$} & Mean & 0.01 & 0.00 & 0.00 & 0.04 & 0.01 & 0.00 & 0.00 & 0.00 & 0.01 \\
\hline & & St.Dv & 0.42 & 0.22 & 0.23 & 0.60 & 0.16 & 0.00 & 0.11 & 0.11 & 0.28 \\
\hline & & $\begin{array}{l}\% \text { cases with } \\
\text { CDAR }>0\end{array}$ & $0.00 \%$ & $\begin{array}{l}0.06 \\
\%\end{array}$ & $0.04 \%$ & $0.00 \%$ & $\begin{array}{l}0.17 \\
\%\end{array}$ & $0.00 \%$ & $0.00 \%$ & $\begin{array}{l}0.07 \\
\%\end{array}$ & $0.03 \%$ \\
\hline & \multirow{2}{*}{$\begin{array}{l}\mathrm{D} \Delta \mathrm{A} \\
\mathrm{R} \\
\end{array}$} & Mean & 150.00 & 75.00 & 119.00 & 150.00 & 75.00 & 0.00 & 150.00 & 75.00 & 108.00 \\
\hline & & St.Dev & 0.00 & 0.00 & 14.14 & 0.00 & 0.00 & 0.00 & 0.00 & 0.00 & 0.00 \\
\hline \multirow{5}{*}{$\begin{array}{l}\text { Moody's } \\
\text { Medium } \\
\text { and } \\
\text { Long } \\
\text { term }\end{array}$} & \multirow{3}{*}{$\begin{array}{l}\mathrm{C} \Delta \mathrm{A} \\
\mathrm{R}\end{array}$} & Mean & 0.02 & 0.01 & 0.01 & 0.07 & 0.05 & 0.03 & 0.01 & 0.01 & 0.01 \\
\hline & & St.Dv & 0.77 & 0.54 & 0.54 & 1.03 & 0.95 & 0.84 & 0.17 & 0.23 & 0.51 \\
\hline & & $\begin{array}{l}\% \text { cases with } \\
\text { CDAR }>0\end{array}$ & $0.00 \%$ & $\begin{array}{l}0.06 \\
\%\end{array}$ & $0.08 \%$ & $0.00 \%$ & $\begin{array}{l}0.48 \\
\%\end{array}$ & $0.11 \%$ & $0.00 \%$ & $\begin{array}{l}0.13 \\
\% \\
\end{array}$ & $0.09 \%$ \\
\hline & $\mathrm{D} \Delta \mathrm{A}$ & Mean & 147.53 & 73.00 & $84.16^{* * *}$ & 150.00 & 75.00 & 0.00 & 150.00 & 75.00 & $63.02^{* * *}$ \\
\hline & $\mathrm{R}$ & St.Dev & 0.00 & 0.00 & 31.88 & 0.00 & 0.00 & 0.00 & 0.00 & 0.00 & 9.62 \\
\hline \multirow{5}{*}{$\begin{array}{l}\text { S\&P } \\
\text { Short term }\end{array}$} & \multirow{3}{*}{$\begin{array}{l}\mathrm{C} \Delta \mathrm{A} \\
\mathrm{R}\end{array}$} & Mean & 0.00 & 0.02 & 0.02 & 0.00 & 0.00 & 0.00 & 0.00 & 0.02 & 0.02 \\
\hline & & St.Dv & 0.22 & 0.71 & 0.75 & 0.02 & 0.00 & 0.00 & \begin{tabular}{|l|}
0.07 \\
\end{tabular} & 0.83 & 0.82 \\
\hline & & $\begin{array}{l}\% \text { cases with } \\
\mathrm{CDAR}>0\end{array}$ & $0.00 \%$ & $\begin{array}{l}0.08 \\
\%\end{array}$ & $0.09 \%$ & $0.00 \%$ & $\begin{array}{l}0.00 \\
\%\end{array}$ & $0.00 \%$ & $0.00 \%$ & $\begin{array}{l}0.07 \\
\%\end{array}$ & $0.08 \%$ \\
\hline & \multirow{2}{*}{$\begin{array}{l}\mathrm{D} \triangle \mathrm{A} \\
\mathrm{R} \\
\end{array}$} & Mean & 150.00 & 75.00 & $52.29^{*}$ & 74.96 & 0.00 & 0.00 & 150.00 & 75.00 & $40.40^{* * *}$ \\
\hline & & St.Dev & 0.00 & 0.00 & 33.10 & 0.00 & 0.00 & 0.00 & 0.00 & 0.00 & 18.01 \\
\hline \multirow{5}{*}{$\begin{array}{l}\text { S\&P } \\
\text { Medium } \\
\text { And } \\
\text { Long } \\
\text { term }\end{array}$} & \multirow{3}{*}{$\begin{array}{l}\mathrm{C} \Delta \mathrm{A} \\
\mathrm{R}\end{array}$} & Mean & 0.01 & 0.03 & 0.03 & 0.00 & 0.00 & 0.00 & 0.00 & 0.03 & 0.03 \\
\hline & & St.Dev & 0.54 & 1.08 & 1.16 & 0.02 & 0.00 & 0.00 & 0.07 & 1.07 & 1.07 \\
\hline & & $\begin{array}{l}\% \text { cases with } \\
\mathrm{CDAR}>0\end{array}$ & $0.00 \%$ & $\begin{array}{l}0.10 \\
\%\end{array}$ & $0.09 \%$ & $0.00 \%$ & $\begin{array}{l}0.00 \\
\%\end{array}$ & $0.00 \%$ & $0.00 \%$ & $\begin{array}{l}0.06 \\
\%\end{array}$ & $0.09 \%$ \\
\hline & \multirow{2}{*}{$\begin{array}{l}\mathrm{D} \Delta \mathrm{A} \\
\mathrm{R}\end{array}$} & Mean & 150.00 & 75.00 & $50.13^{*}$ & 74.96 & 0.00 & 0.00 & 150.00 & 75.00 & $51.00^{*}$ \\
\hline & & St.Dev & 0.00 & 0.00 & 31.79 & 0.00 & 0.00 & 0.00 & 0.00 & 0.00 & 36.37 \\
\hline
\end{tabular}

The analysis of $\mathrm{C} \Delta \mathrm{AR}$ demonstrated that normally rating assigned in not influenced by corporate events that attain group structure because for all agencies and for all type of rating less than $1 \%$ of cases considered present a $\mathrm{C} \Delta \mathrm{AR}$ higher than zero. Looking at each type of event, the rating revision after a corporate event is more relevant after acquisitions and normally irrelevant after merging activities. On the basis of the mean amount of rating changes in the event window, Moody's presents a medium-long term rating that is more sensitive to group corporate events while short term ratings define by $\mathrm{S} \& \mathrm{P}$ are those that are more affected. Fitch is the rating agency for which the response to group structure change is more frequently void for all ratings considered ${ }^{6}$.

The rating revision, when occurs, is normally a reaction to the new information available because, except for Fitch medium and long term rating revision related to disposal of asset, liabilities or branch, the mean value of $\mathrm{D} \Delta \mathrm{AR}$ is always 150 days for the ex-ante event window and 75 days for infra-event window: this result demonstrate that the agency is unable to predict the change in the group structure and normally react only in the day of the event. Statistical tests on the significance of DDAR support this thesis because normally the difference is not significant and the small number of scenarios in which the test are satisfied are only ex-post ones. The analysis of the ex-post event window demonstrates that S\&P has an higher capability to make the rating revision in the shorter time.

\section{Conclusions}

Group exposure to specific and systematic risk factors is influenced by the relationships among the members.

\footnotetext{
${ }^{6}$ Result obtained are partially explainable on the basis of the different number of rating issued by each rating agency for Italian banking groups' members that is normally lower for Fitch.
} 
Rating agencies state in their criteria that the formulation of an independent judgment on the group characteristics, expressed alongside the judgments on the group entities and their issues (Fitch), or providing for a direct adjustment of the judgments regarding the individual members and/or the issues based on the group characteristics (S\&P and Moody's respectively).

The empirical evidence from a sample of Italian banking groups shows how the rating judgments are hardly variable over time (Fitch), regardless of the occurrence of any corporate events that, based on the criteria, should affect the agency's rating and are predominantly related to the rating trends of the holding company.

The analysis of the ratings adjusted in accordance with the group characteristics shows that normally rating of group' members do not react to change in the overall structure and normally these few changes are almost all ex-post revisions. For those rating that changes, a ranking among agencies on the basis of the amount and on the time necessary for the revision could be defined: Moody's presents higher sensitivity to these events and S\&P is the agency that normally is able to react in the shorter time.

The analysis of the criteria produced by the agencies has highlighted that the changes in the group ratings do not depend only on the occurrence of extraordinary events, as considered in the paper, but also on changes to the group's other organization and asset/liability characteristics. The study of the relationship between group characteristics and ratings, therefore, should be completed by a study of the significance of the organisational changes and of the group's financial statements, with respect to the judgments expressed by the agencies.

From a creditor's point of view, results obtained entail that the ratings by the agencies cannot be used as suitable assessments of the group risk, with respect to the financing transactions of the group and/or the group entities and to the determination of the regulatory capital.

\section{References}

Allen, L. and Jagtiani, J. (2000). The risk effects of combining banking, securities, and insurance activities. Journal of Economics and Business, 52, 485-497.

Azzini, L. (1968). I gruppi, lineamenti politico aziendali. Milan: Giuffrè.

Bank of Italy (1999). Istruzioni di vigilanza per le banche, Circolare 229 aggiornamenti and updates

Bank of Italy (2008). Annual Report, available at http://www.bancaditalia.it/pubblicazioni/relann/rel07/encf07/rel_07_abr_anrep.pdf (accessed 01-05-2009).

Baravelli, M., (2003). Strategia e organizzazione della banca. Milan: EGEA.

Basel Committee on Banking Supervision (2000). Sound practices for managing liquidity in banking organization. Bank for International Settlement, February.

Basel Committee on Banking Supervision, (2006). Basel II: international convergence of capital measurement and capital standards - a revised framework. Bank for International Settlement, June.

Berger, A.N. and Hannan, T.H. (1998). The efficiency cost of market power in the banking industry: a test of the "quiet life" and related hypotheses. Review of Economics Statistics, 80, 454-465.

Bissoondoyal-Bheenick, E. (2005). An analysis of the determinants of sovereign ratings. Global Finance Journal, 15, 251-280.

Bowman, R.G., (1983). Understanding and conducting event studies. Journal of Business Financial Accounting, 10, 561-584. 
Brioschi, F., Buzzacchi L. and Colombo, M.G. (1990). Gruppi di imprese e mercato finanziario. La struttura di potere nell'industria italiana. Rome: La Nuova Italia Scientifica.

Cantor, R. (2004). An introduction to recent research in credit ratings. Journal of Banking Finance, 28, 2565-2573.

Carretta, A. (1986). Le banche e la gestione delle attività non bancarie: alcuni profili organizzativi. Banca, Impresa e Società, 5, 81-95.

Cassandro, P. (1969). I gruppi aziendali. Naples: Cacucci.

Cowan, A. (1991). Inside information and debt rating changes. Journal of Midwest Finance Association, 20, 47-58.

Cumming, M. and Hirtel B.J. (2001). The challenges of risk management in diversified financial companies. Federal Reserve Bank New York Economic Policy Review, 7, 117.

Cybo-Ottone A. and Murgia M. (2000). Mergers and shareholder wealth in European Banking. Journal of Banking \& Finance, 24, 831-859.

D'Souza, C. and Lai, A. (2007). The effects of bank consolidation on risk capital allocation and market liquidity. Bank of Canada working paper, April.

Demsetz, R.S. and Strahan, P.E. (1997). Diversification, size, and risk at bank holding companies. Journal of Money, Credit, Banking, 29, 300-313.

Edwards, P. (1999). Managing risk and capital in financial conglomerates. Australian Prudential Regulation Authority, September.

Ertugrul, M. and Hedge, S. (2010). Corporate Governance Rating and Firm Performance. Financial Management, forthcoming.

European Central Bank (2008). EU Banking Structures. available at http://www.fininc.eu/gallery/documents/otherdocuments/bibliography/eubankingstructures2008en.pdf (accessed 01-05-2009).

Fitch (2004). Bank rating methodology. Criteria report, London.

Fitch (2006). Holding company analysis - banks and similar financial institutions. London: Criteria report.

Gaver, J.J. and Pottier, S.W. (2005). The role of holding company financial information in the insurer rating process: evidence from the property liability industry, Journal of Risk Insurance, 72, 77-103.

Goddard, J., Molyneux, P., Wilson, J.O.S. and Tavakoli, M. (2007). European banking: An overview, Journal of Banking \& Finance, 31, 1911-1935.

Guatri, L. and Bini M. (2007). La valutazione delle aziende. Milan: EGEA.

Joint Forum (2008). Cross-sectoral review of group-wide identification and management of risk concentrations. Bank for International Settlements, April.

Kao, C. and Wu, C. (1990). Two step estimation of linear models with ordinal unobserved variables: the case of corporate bonds. Journal of Business Economic Statistics, 8, 317-325.

Lown, C.S., Osler, C.L., Strahan, P.E. and Sufi, A. (2000). The changing landscape of the financial service industry: what lies ahead. Federal Reserve Bank New York Economic Policy Review, 6, 39-55.

Mackinlay, C.A. (1997). Event studies in economics and finance. Journal of Economic Literature, 35, 13-39.

Masini, M., 1988. Le politiche dei prezzi di trasferimento nelle imprese bancarie. in Masini, M., Comana M. and Previati D. (eds). Prospettive di programmazione controllo nelle banche. Milan: Giuffrè.

Moody's (1999). Bank credit risk: an analytical frame work for banks in developed countries. Rating Methodology, New York. 
Moody's (2003). Bank liquidity risk and short-term bank deposit ratings. Rating Methodology, New York.

Moody's (2006). Bank financial strength ratings: global methodology. Rating Methodology, New York.

Monferrà, S. and Rigodanza, L. (2006). Il rischio di credito nel caso dei gruppi di imprese. in Carretta, A., Filotto, U., Fiordelisi, F. (eds). Informazione e governo del rischio di credito. Milan: Franco Angeli.

Mottura, P. (2007). Banche - Strategie, organizzazione e concentrazione. Milan: Egea.

Partnoy, F. (1999). The siskel and ebert of financial markets: two thumbs down for the credit rating agencies. University Washington Law Quarterly, 77, 619-715.

Pisoni, P. (1983). Gruppi aziendali e bilanci di gruppo. Milan: Giuffrè.

Ruozi, R. (2006). Economia e gestione della banca, Milan: Egea.

Soda, G., 1988, Reti tra imprese. Rome: Carocci.

Standard and Poor's (2004a). FI criteria: rating banks. Rating Methodology, New York.

Standard and Poor's (2004b). FI criteria: group methodology for financial services companies. Rating Methodology, New York.

Teece, D.J. (1980). Economies of scope and the scope of the enterprise. Journal of Economical Behavioural Organization, 1, 223-247.

Vander Vennet, R. (2002). Cost and profit efficiency of financial conglomerates and universal banks. European Journal of Money, Credit and Banking, 34, 254-282. 